\title{
Dinamika Ketenagakerjaan pada Wilayah Pedesaan Lahan Kering di Indonesia
}

\section{Employment Dynamics in Rural Areas in Indonesia Dryland}

\author{
Bambang Winarso \\ Pusat Sosial Ekonomi dan Kebijakan Pertanian, Bogor
}

\begin{abstract}
Indonesian Population increasing, the other side of the jobs that are limited, it is problems. As a country, agraris reality shows that availability of jobs was largely in agriculture sector. Inhabitant of indonesia development increasing while on the other side of the jobs that are limited, it is still problems. Its reality shows that availability of jobs was largely in agriculture sector. This was demonstrated by the source of livelihood largely from agriculture. As we know that in a domicile of agricultural labors being in the region with agroekosystem dryland which is sometimes tinged by the marginal land. Relating to employment been trying to highlight structure labour participation, especially in terms of level good chance and labour force, according to age, level of education, and types of work as well as people in rural areas, mobilization especially in village with agroekosistem dry land. The provinces that being the location where research is Lampung, South Sulawesi East Java, Central Java and West Java. The result showed that viewed from accessibility, job opportunities then accessibility of labor in this area use hasnt job opportunities outside agriculture. If the employment opportunities, the work got generally the same work often they do in the provenance as labor and transport services.
\end{abstract}

Keywords: employment dynamics, rural areas and dryland

Diterima: 29-09-2013, disetujui: 17-01-2014

\section{PENDAHULUAN}

Indikator tidak langsung tingkat pendapatan rumah tangga sebagai representasi tingkat kesejahteraan di sektor pertanian yang berkaitan dengan tenaga kerja adalah produktivitas tenaga kerja dan tingkat pengangguran. Produktivitas tenaga kerja di sektor pertanian diukur dari pendapatan total yang diperoleh dari seluruh jenis kegiatan yang dilakukan anggota rumah tangga dibagi dengan jumlah anggota rumah tangga yang bekerja. Apabila produktivitas tenaga kerja di sektor pertanian relatif rendah maka secara tidak langsung akan diperoleh gambaran bahwa tingkat pendapatan rumah tangga di sektor pertanian akan relatif rendah. Sementara tingkat pengangguran diukur dari banyaknya anggota rumah tangga yang menganggur atau tidak memiliki pekerjaan. Apabila tingkat pengangguran di sektor pertanian relatif tinggi secara tidak langsung akan diperoleh gambaran bahwa tingkat pendapatan rumah tangga di sektor pertanian rata-rata akan relatif rendah. Realitas menunjukkan bahwa produktivitas tenaga kerja di sektor pertanian selalu lebih kecil daripada produktivitas tenaga kerja di luar sektor pertanian.

Rusastra et al., 2005 mengemukakan bahwa unsur penting dari tenaga kerja manusia yang dapat menghasilkan pendapatan adalah keahlian dan tenaga. Keahlian sebagai representasi kualitas 
tenaga kerja manusia biasanya diproksi dari tingkat pendidikan formal dan ketrampilan yang dimiliki. Bagi sebagian besar tenaga kerja yang terlibat di sektor pertanian unsur penting yang mereka miliki adalah tenaga. Dalam hal ini tenaga kerja manusia memberikan kontribusi terhadap pendapatan rumah tangga petani lewat curahan tenaga kerja manusia yang terlibat (dalam satuan orang) dan curahan kerjanya (dalam satuan jam ker per hari, hari kerja per minggu, per bulan, per tahun)

Berkaitan dengan tenaga kerja manusia, kebijakan dan program pembangunan sektor pertanian maupun di luar sektor pertanian akan berpengaruh baik terhadap kualitas (tingkat pendidikan formal dan ketrampilan), banyaknya tenaga kerja yang terlibat maupun terhadap curahan kerja. Tingkat pendidikan formal tenaga kerja manusia lebih banyak dipengaruhi oleh kebijakan dan program pembangunan di luar sektor pertanian dalam hal ini Kementerian Pendidikan Nasional. Ketrampilan tenaga kerja manusia khususnya yang terlibat di sektor pertanian lebih banyak dipengaruhi oleh kebijakan dan program pembangunan sektor pertanian lewat kegiatan-kegiatan pelatihan, sekolah lapang maupun penyuluhan. Sementara itu banyaknya tenaga kerja yang terlibat maupun curahan kerjanya sangat dipengaruhi oleh kesempatan kerja yang diciptakan oleh kebijakan dan program pembangunan baik di sektor pertanian maupun di diluar sektor pertanian.

Hasil penelitian Patanas tahun 1984 menyimpulkan bahwa sebagian besar pendapatan rumahtangga berasal dari sektor pertanian, akan tetapi usaha di luar pertanian juga memberikan kontribusi pendapatan cukup besar misalnya perdagangan, pegawai dan buruh nonpertanian seperti jasa angkutan dan industri rumahtangga. Pola berpenghasilan ganda tersebut tidak terbatas pada individu (kepala keluarga rumahtangga) yang tidak memiliki lahan, tetapi juga pada golongan pemilik lahan yang juga menikmati penghasilan di luar pertanian yang lebih tinggi, hal ini diperkuat oleh temuan (White, 1981 dalam White, 1990). Hasil penelitian Syukur et al. (1988), dan Marisa dan Hubarat (1988) yang menunjukkan bahwa distribusi pendapatan rumah tangga di perdesaan tergolong kedalam ketimpangan yang tinggi. Artinya desa-desa dengan potensi lahan kering terjadi ketimpangan pendapatan di luar sektor pertanian sebagai akibat dari ketimpangan distribusi penguasaan modal dan keterampilan.

Berkaitan dengan ketenagakerjaan kajian ini mencoba menyoroti struktur tenaga kerja terutama dalam hal tingkat partisipasi, kesempatan dan angkatan kerja baik menurut umur, tingkat pendidikan, dan jenis pekerjaan serta mobilisasi penduduk di pedesaan. Perlu diketahui bahwa tulisan ini merupakan hasil penelitian Panel Petani Nasional (PATANAS) tahun 2008 dan tahun 2011 yang dilakukan oleh Pusat Sosial Ekonomi dan Kebijakan Pertanian, Badan Litbang Pertanian. Kegiatan penelitian dilakukan pada tahun 2011 di agroekosistem lahan kering berbasis palawija dimana propinsi-propinsi yang menjadi lokasi penelitian adalah Lampung, Sulawesi Selatan, Jawa Timur, Jawa Tengah, dan Jawa Barat (Tabel 1).

Tabel 1. Desa-Desa Contoh PATANAS Untuk Tipe Desa Lahan Kering Berbasis Komoditas Sayuran dan Palawija Menurut Propinsi

\begin{tabular}{lllll}
\hline No. & Propinsi & \multicolumn{1}{c}{ Kabupaten } & Desa & Komoditas Basis \\
\hline 1 & Lampung & Tulang Bawang & Catur Karya BJ & Ubi kayu \\
2 & Sulawesi Selatan & Bulukumba & Balleanging & Jagung \\
3 & Jawa Timur & Blitar & Bumiayu & Jagung \\
4 & Jawa Timur & Probolinggo & Resongo & Jagung \\
5 & Jawa Tengah & Wonogiri & Ngelo & Kacang Tanah \\
6 & Jawa Tengah & Pati & Tlogosari & Ubikayu \\
7 & Jawa Barat & Garut & Mekarsari & Kacang Tanah \\
8 & Jawa Barat & Garut & Sindangmekar & Kedelai \\
\hline
\end{tabular}


Sementara itu konsep dan definisi tentang ketenaga-kerjaan yang digunakan dalam tulisan ini mengacu pada Badan Pusat Statistik, dimana membagi penduduk menjadi dua kelompok, yaitu penduduk usia kerja dan penduduk bukan usia kerja. Selanjutnya, penduduk usia kerja dibedakan pula menjadi dua kelompok berdasarkan kegiatan utama yang sedang dilakukannya. Kelompok tersebut adalah angkatan kerja dan bukan angkatan kerja.

\section{HASIL DAN PEMBAHASAN}

Masalah ketenagakerjaan di Indonesia bekisar pada sekurang-kurangnya empat macam ketidak-seimbangan yang bersifat struktural yaitu: Pertama, terbatasnya lapangan kerja produktif dan tingginya tingkat pertumbuhan angkatan kerja terutama kelompok angkatan kerja berusia muda yang menyebabkan kelebihan tenaga kerja. Kedua, penyebaran angkatan kerja secara geografis dalam hubungannya dengan penyebaran potensi sumber daya alam, khususnya tanah pertanian, mengakibatkan hambatan-hambatan dalam memanfaatkan tenaga kerja yang ada secara optimal. Ketiga, masih adanya ketidak seimbangan di antara jenis dan jumlah tenaga yang dibutuhkan dengan jenis dan jumlah tenaga yang dihasilkan melalui sistem pendidikan dan latihan. Keempat, pasar tenaga kerja yang belum berfungsi sepenuhnya dalam menyalurkan tenaga kerja secara berhasil guna dan berdaya guna.

Indonesia sebagai negara agraris, ketersediaan lapangan pekerjaan sebagian besar berada disektor pertanian. Hal ini setidaknya ditunjukkan oleh besarnya sumber mata pencaharian penduduk Indonesia yang sebagian besar dari sektor pertanian. Data menunjukkan bahwa posisi 2011 tenaga kerja Indonesia yang bekerja di sektor pertanian sebesar 38,06 juta orang (Statistik Pertanian, 2012). Kurang menjanjikannya pendapatan bekerja di sektor pertanian, menyebabkan banyak penduduk usia kerja bekerja di non pertanian. Gambaran tentang keadaan penduduk, jumlah Anggota Rumah Tangga (ART), jumlah Kepala Keluarga (KK) dan Angkatan Kerja di lokasi contoh ditampilkan dalam Tabel 2 .

Tabel 2 Keadaan Penduduk di Desa Berbasis Agroekosistem Komoditas Palawija dan Sayuran di Perdesaan Patanas tahun 2008 dan 2011

\begin{tabular}{|c|c|c|c|c|c|c|c|c|c|c|c|c|}
\hline \multirow{2}{*}{$\begin{array}{c}\text { Basis } \\
\text { Komoditas/ } \\
\text { Desa }\end{array}$} & \multirow{2}{*}{$\begin{array}{c}\text { Jml } \\
\text { ART } \\
\text { (jiwa) }\end{array}$} & \multirow{2}{*}{$\begin{array}{l}\text { Jml } \\
\mathrm{KK}\end{array}$} & \multicolumn{3}{|c|}{$\begin{array}{c}\text { Angkatan Kerja } 2008 \\
\text { (jiwa) }\end{array}$} & \multirow{2}{*}{$\begin{array}{c}\text { Bukan } \\
\text { AK }(<15 \\
\text { thn })\end{array}$} & \multirow{2}{*}{$\begin{array}{c}\text { Jml } \\
\text { ART } \\
\text { (jiwa) }\end{array}$} & \multirow{2}{*}{$\begin{array}{l}\mathrm{Jml} \\
\mathrm{KK}\end{array}$} & \multicolumn{3}{|c|}{$\begin{array}{c}\text { Angkatan Kerja } 2011 \\
\text { (jiwa) }\end{array}$} & \multirow{2}{*}{$\begin{array}{c}\text { Bukan } \\
\text { AK }(<15 \\
\text { thn })\end{array}$} \\
\hline & & & Bekerja & $\begin{array}{c}\text { Tdk } \\
\text { Bekerja }\end{array}$ & Jumlah & & & & Bekerja & $\begin{array}{c}\text { Tdk } \\
\text { Bekerja }\end{array}$ & Jumlah & \\
\hline \multicolumn{13}{|l|}{ A. Palawija } \\
\hline 1. Resongo & 620 & 150 & 429 & 39 & 468 & 152 & 134 & 32 & 74 & 15 & 96 & 38 \\
\hline 2. Bumiayu & 503 & 151 & 356 & 55 & 411 & 92 & 134 & 32 & 54 & 14 & 98 & 36 \\
\hline 3. Tlogosari & 534 & 149 & 307 & 91 & 398 & 136 & 120 & 32 & 59 & 26 & 88 & 32 \\
\hline 4. Ngelo & 696 & 152 & 457 & 106 & 563 & 133 & 148 & 32 & 86 & 24 & 112 & 36 \\
\hline 5. Sindang Mekar & 608 & 149 & 316 & 94 & 410 & 198 & 145 & 32 & 65 & 23 & 91 & 54 \\
\hline 6. Mekarsari & 572 & 150 & 312 & 84 & 396 & 176 & 140 & 32 & 70 & 19 & 93 & 47 \\
\hline 7. Catur KBJ & 420 & 110 & 261 & 56 & 317 & 103 & 105 & 25 & 53 & 27 & 78 & 27 \\
\hline 8. Balleanging & 409 & 97 & 223 & 54 & 277 & 132 & 108 & 25 & 51 & 26 & 79 & 29 \\
\hline Total & 4.362 & 1.108 & 2.661 & 579 & 3.240 & 1.122 & 1.034 & 242 & 512 & 169 & 706 & 299 \\
\hline
\end{tabular}

Sumber : Data primer (diolah) 


\section{Keadaan Penduduk}

Secara umum penduduk ditempatkan sebagai (1) input produksi, dalam menyediakan tenaga kerja yang diperlukan dalam proses produksi, dan (2) sebagai konsumen, karena menggunakan berbagai sumberdaya ekonomi, dan memiliki peran mengkonsumsi sumberdaya ekonomi yang tersedia. Padahal sumberdaya yang tersedia jumlahnya amat terbatas, dibanding jumlah penduduk yang terus meningkat. Persoalan-persoalan seperti kemiskinan, ketimpangan distribusi pendapatan dan sebagainya sebenarnya merupakan juga masalah kependudukan. Hasil studi yang dilakukan oleh Supriati (2010) dan Malian et al. (2004) menunjukkan bahwa dalam periode 20 tahun (1983 - 2003) telah terjadi pergeseran yang cukup signifikan, dimana proporsi petani di Indonesia menurun dan buruh tani meningkat. Kejadian tersebut menunjukkan bahwa telah terjadi pergeseran tenaga kerja terutama dari pertanian ke non pertanian. Akan tetapi sifatnya masih terbatas dan sektor pertanian masih merupakan tumpuan hidup rumahtangga pertanian di pedesaan. Hal ini diperkuat oleh hasil studi yang dilakukan oleh Sholeh (2007) yang juga menunjukkan bahwa ketenagakerjaan di Indonesia hingga kini masih menghadapi beberapa ketidak seimbangan baik struktural maupun sektoral, walaupun telah terjadi pergeseran, namun sebagian besar angkatan kerja Indonesia masih bekerja di sektor pertanian. Salah satu permasalahan kemiskinan di pedesaan yang perlu mendapat pertimbangan adalah terbatasnya masyarakat akses terhadap kesempatan kerja yang berkelanjutan (Sudaryanto dan Rusastra, 2006).

Berdasarkan tingginya tingkat usia maka jumlah penduduk diatas usia 15 tahun lebih besar jumlahnya dibanding angkatan kerja dibawah 15 tahun. Hal ini menunjukkan bahwa dipedesaan tingginya proporsi jumlah penduduk diatas 15 tahun merupakan sumber potensi tenaga kerja produktif untuk memenuhi pasar tenaga kerja di sektor pertanian dan non pertanian. Rata-rata jumlah penduduk usia produktif pada tahun 2008 sebesar 74,1\%. Jumlah penduduk (ART) yang berusia dibawah 15 (anak-anak) pada tahun 2008 sebesar 25,9\%, dan meningkat menjadi 28,7\%. Pada tahun 2011 ratarata jumlah ART menurut kelompok umur diatas 15 tahun tidak menunjukkan perubahan yang signifikan. Rata-rata jumlah ART sedikit meningkat dari 3,9 orang pada tahun 2008 menjadi 4,3 orang pada tahun 2011 seperti disajikan dalam tabel 3

Pengelompokkan penduduk menurut umur dapat digunakan untuk mengetahui apakah penduduk di suatu wilayah termasuk berstruktur umur muda atau tua. Penduduk suatu wilayah dianggap penduduk muda apabila penduduk usia dibawah 15 tahun mencapai sebesar $40 \%$ atau lebih dari jumlah seluruh penduduk. Sebaliknya penduduk disebut penduduk tua apabila jumlah penduduk usia 65 tahun keatas diatas $10 \%$ dari total penduduk. Pada wilayah yang mempunyai karakteristik penduduk muda akan mempunyai beban besar dalam investasi sosial untuk pemenuhan kebutuhan pelayanan dasar bagi penduduk $<15$ tahun (anak-anak). Dalam hal ini pemerintah harus membangun sarana dan prasarana pelayanan dasar mulai dari perawatan Ibu hamil dan kelahiran bayi, bidan dan tenaga kesehatan lainnya, serta penyediaan pendidikan anak usia dini, sekolah dasar termasuk guruguru dan sarana sekolah yang lain. Sebaliknya wilayah dengan ciri penduduk tua akan mengalami beban yang cukup besar dalam pembayaran pensiun, perawatan kesehatan fisik dan kejiwaan lanjut usia (lansia), pengaturan tempat tinggal dan lain-lain.

Jumlah penduduk menurut kelompok umur penting diketahui agar pembangunan dapat diarahkan sesuai kebutuhan penduduk sebagi pelaku pembangunan. Disamping itu, sangat penting dan dibutuhkan berkaitan dengan pengembangan kebijakan kependudukan terutama berkaitan dengan pengembangan sumberdaya manusia. Jumlah penduduk yang besar dapat dipandang sebagai beban sekaligus juga modal dalam pembangunan. Dengan mengetahui jumlah dan persentase penduduk di tiap kelompok umur, dapat diketahui berapa besar penduduk yang berpotensi menanggung beban 
penduduk yang belum produktif ( $<15$ tahun) dan penduduk yang dianggap kurang produktif/tidak produktif (65 tahun ke atas).

Tabel 3: Jumlah penduduk, angkatan kerja dan tingkat partisipasi kerja di pedesaan agroekoistem lahan kering, 2011

\begin{tabular}{|c|c|c|c|}
\hline \multirow{2}{*}{ No } & \multirow{2}{*}{ Keterangan } & \multicolumn{2}{|c|}{ Tahun } \\
\hline & & 2008 & 2011 \\
\hline \multirow[t]{5}{*}{1} & Rataan jumlah KK dan jumlah kelompok umur & & \\
\hline & a. Rataan jiwa/KK & 3,9 & 4,3 \\
\hline & b. Jumlah penduduk menurut kel. Umur & & \\
\hline & $-<15$ tahun & 25,9 & 28,7 \\
\hline & - >= 15 tahun & 74,1 & 71,3 \\
\hline \multirow[t]{5}{*}{2} & Prosentase tingkat partisipasi angkatan kerja & & \\
\hline & a. Partisipasi kerja & 81,91 & 72,30 \\
\hline & b. Kesempatan kerja & 60,79 & 49,52 \\
\hline & c. angkatan kerja & 74,06 & 68,28 \\
\hline & d. Penganguran & 13,27 & 16,34 \\
\hline \multirow[t]{5}{*}{3} & Angkatan kerja menurut pendidikan & & \\
\hline & a. Tdk sekolah s/d tamat SD & 69,2 & 70,0 \\
\hline & b. Tdk tamat SMP s/d tamat SMP & 18,4 & 17,6 \\
\hline & c. Tdk tamat SMA s/d tamat SMA & 10.8 & 10,3 \\
\hline & d. Diploma/perguruan tinggi & 1,7 & 2,0 \\
\hline \multirow[t]{9}{*}{4} & Angkatan kerja menurut kelompok umur & & \\
\hline & A. Bekerja di bidang pertanian & & \\
\hline & a. $15-34$ thn & 16,9 & 25,1 \\
\hline & b. $35-54$ thn & 42,8 & 35,1 \\
\hline & c. $>54$ thn & 11,8 & 15,6 \\
\hline & B. Bekerja diluar bidang pertanian & & \\
\hline & a. 15 - 34 thn & 13,6 & 14,5 \\
\hline & b. $35-54$ thn & 13,6 & 7,9 \\
\hline & c. $>54$ thn & 1,4 & 1,9 \\
\hline
\end{tabular}

\section{Partisipasi Tenaga Kerja dan Pengangguran}

Bekerja merupakan salah satu kegiatan yang mencerminkan aktivitas ekonomi suatu wilayah. Semakin banyak penduduk yang bekerja maka akan semakin positif dampaknya terhadap kehidupan sosial ekonomi suatu wilayah. Dengan semakin banyak penduduk yang bekerja dan sedikit penduduk yang menganggur, pemerintah akan semakin ringan dalam menangani masalah penyerapanpenyerapan tenaga kerja. Peran penduduk akan menjadi modal dasar pembangunan bila diupayakan dengan baik, sebaliknya akan menjadi beban yang berat bila tidak diberdayakan dengan baik. Tingkat Partisipasi Angkatan Kerja (TPAK) adalah salah satu ukuran ketenegakerjaan yang banyak digunakan. Pengukuran TPAK dilakukan dengan cara menghitung jumlah absolut seluruh angkatan kerja dibagi dengan seluruh tenaga kerja yang berkeja kemudian dikalikan 100. Jika TPAK 75\%, artinya dalam setiap 100 orang tenaga kerja terdapat 75 orang angkatan kerja yang bekerja. Berdasarkan TPAK kita dapat melakukan perkiraan, berapa besar penduduk usia kerja yang berpartisipasi dalam aktivitas 
ekonomi. Peningkatan angkatan kerja tanpa diikuti dengan TPAK, akan menimbulkan tingkat pengangguran yang tinggi dan pada gilirannya menghambat jalannya pembangunan.

Definisi tenaga kerja adalah penduduk berusia 15 tahun atau lebih. Tenaga kerja terdiri dari angkatan kerja dan bukan angkatan kerja. Kelompok angkatan kerja terdiri dari golongan yang bekerja dan golongan tidak bekerja (mencari pekerjaan). Sementara itu kelompok bukan angkatan kerja terdiri dari golongan yang bersekolah, mengurus rumahtangga dan golongan lain penerima pendapatan (Simanjuntak, 1985).

Dalam beberapa hal konsep tenaga kerja menurut BPS, bahwa persepsi angkatan kerja didefinisikan adalah penduduk berumur 15 tahun keatas yang selama seminggu sebelum pencacahan berstatus bekerja atau mempunyai pekerjaan tetapi sementara tidak bekerja, dan mereka tidak bekerja tetapi sedang mencari pekerjaan. Sedangkan persepsi partisipasi angkatan kerja didefinisikan sebagai perbandingan antara jumlah angkatan kerja dengan seluruh penduduk, tingkat partisipasi kerja didefinisikan sebagai rasio jumlah angkatan kerja yang bekerja dengan jumlah angkatan kerja, kesempatan kerja merupakan rasio jumlah angkatan kerja yang bekerja dengan jumlah penduduk, dan tingkat pengangguran rasio jumlah angkatan kerja yang tidak bekerja dengan jumlah penduduk. Secara agregat data tabel lampiran 1 juga mengemukakan bahwa pada tahun 2008 tingkat partisipasi kerja di pedesaan berbasis komoditas palawija adalah $81,91 \%$. Sementara itu bila dirinci dari beberapa desa tingkat partisipasi kerja, angkatan kerja, dan kesempatan kerja yang tinggi dan tingkat pengangguran yang rendah berturut-turut adalah Desa Resongo dan Desa Bumiayu, sedangkan pada tahun 2011 besarnya tingkat partisipasi kerja secara prosentase justru mengalami penurunan menjadi $72,3 \%$.

Tingginya TPAK pedesaan, paling tidak dapat ditafsirkan dari dua sisi. Pertama, kemungkinan etos kerja masyarakat di perdesaan memang tinggi, sehingga mereka kebanyakan bergiat dalam aktivitas ekonomi. Kedua, bisa pula mereka masuk ke dunia kerja karena terpaksa, akibat adanya himpitan kehidupan yang begitu kuat, sehingga mau tidak mau mereka harus bekerja agar dapat bertahan hidup. Sedangkan tingginya tingkat pengangguran menunjukan bahwa pemanfaat peluang kerja menurut sumber matapencahariaan yang ada belum diupayakan secara optimal atau dengan perkataan lain belum ada kesempatan kerja yang dapat dimanfaatkan oleh angkatan kerja. Yang pada akhirnya akan menjadi beban bagi anggota rumahtangga yang bekerja.

Beberapa hal yang mempengaruhi tingkat partisipasi kerja dan tingkat pengangguran adalah;

1) Tingginya tingkat aksesibilitas desa terhadap sumber pertumbuhan ekonomi, 2) Peranan sarana prasarana dan transportasi yang mudah menjangkau keberbagai sumber matapencaharian di pertanian dan non pertanian, 3) Akses penguasaan dan garapan lahan yang marginal yang mendorong untuk melakukan diversikasi keberbagai sumber matapencaharian, 4) Tingkat pengetahuan dan pendidikan serta wawasan yang dimiliki yang digunakan untuk memilih jenis pekerjaan yang lebih sesuai, 5) Adanya pemutusan hubungan kerja yang kembali kedesa yang akhirnya akan mempengaruhi kesimbangan pasar tenaga kerja dipedesaan.

\section{Angkatan Kerja menurut Tingkat Pendidikan}

Tingkat pendidikan merupakan salah satu faktor yang menentukan kualitas tenaga kerja. Idealnya, tenaga kerja yang tersedia memiliki pendidikan yang memadai sesuai dengan kesempatan kerja yang tersedia, namun biasanya sering terjadi mismatch antara pendidikan dan pekerjaan yang ditekuninya, terutama untuk pekerjaan yang sifatnya formal. Pendidikan tenaga kerja, sering diukur dengan proporsi tenaga kerja berdasarkan pendidikan yang ditamatkan. Data pada tabel 3 menunjukkan bahwa pada tahun 2008 dan 2011 tenaga kerja pedesaan lebih banyak didominasi oleh 
mereka yang tidak pernah mengenyam pendidikan formal atau tidak sekolah, yang tidak tamat SD, dan mereka yang hanya mengantongi ijazah SD. Secara agregat tingkat pendidikan SD ke bawah di desa penelitian mencapai 69,2\% (2008) dan 70\% (2011). Proporsi tingkat pendidikan SD ke bawah tertinggi, baik pada tahun 2008 dan 2011 terdapat di desa Resongo, Kabupaten Probolinggo yang mencapai 94\% (2008) dan 90\% pada tahun 2011.

Sebagai gambaran secara rinci bahwa, tenaga kerja yang memiliki proporsi tertinggi berpendidikan tamat SD adalah desa Bumiayu (kabupaten Blitar) yang mencapai 45\% (2008) dan 42\% (2011). Tingginya proporsi tingkat pendidikan SD kebawah kemungkinan karena masyarakat pedesaan belum begitu mamahami arti penting pendidikan bagi masa depan anak-anaknya. Faktor lain, dan ini mungkin faktor yang paling menentukan, karena biaya untuk meraih pendidikan yang lebih tinggi relatif mahal, sementara sebagian besar masyarakat di pedesaan masih banyak yang tergolong miskin (BPS, 2003).

Pada tahun 2011, jumlah angkatan kerja yang tidak sekolah masih relatif tinggi berkisar 15\%, mereka merupakan bagian dari angkatan kerja yang kurang mampu bersaing dipasar tenaga kerja lebih mengutamakan skill yang tinggi. Sehingga pada gilirannya akan masuk pada sektor yang hanya mengandalkan keterampilan dan pengalaman, seperti kegiatan berburuh di sektor pertanian dan non pertanian. Hal ini memberikan sinyal kepada pemerintah, bahwa masih perlu banyak lagi pembangunan sarana pendidikan setingkat SMP di wilayah pedesaan, sehingga para lulusan SD yang ingin melanjutkan ke SMP tidak perlu lagi pergi ke kota. Dengan demikian, biaya yang dikeluarkan menjadi tidak terlampau mahal, dan secara ekonomi menjadi terjangkau oleh orang tua di pedesaan yang menginginkan anaknya meraih pendidikan yang lebih baik.

Walaupun struktur pendidikan tenaga kerja pedesaan ini nampak sudah mulai membaik, namun jika melihat mereka yang berkualifikasi pendidikan SMA, baik itu umum maupun kejuruan, tingkat diploma, serta mereka yang telah meraih pendidikan sarjana, angkanya masih terlihat tidak seimbang. Jumlah tenaga kerja berpendidikan SMA ke bawah sebesar 10,8\% pada tahun 2008 dan mernurun pada tahun 2011 menjadi 10,3\%.. Apalagi mereka yang memiliki tingkat pendidikan sarjana, secara keseluruhan proporsi tenaga kerja pedesaan masih dibawah $2 \%$ saja dibandingkan tenaga kerja yang berpendidikan dibawahnya.

Hal ini menunjukkan bahwa ketersediaan angkatan kerja untuk pendidikan yang rendah akan menjadi kurang mampu bersaing di pasar tenaga kerja yang memerlukan dan wawasan dan pendidikan yang lebih tinggi. Semuanya itu mengisyaratkan, walaupun telah ada perbaikan struktur pendidikan tenaga kerja pedesaan, akan tetapi masih perlu upaya-upaya untuk lebih meningkatkan kualitas pendidikannya. Mengingat umumnya masyarakat pedesaan masih terjerat kemiskinan, maka kebijakan pendidikan gratis, atau paling tidak kebijakan pendidikan yang murah tapi berkualitas, serta dapat terjangkau oleh hampir semua lapisan masyarakat di pedesaan sangat perlu untuk segera diupayakan.

\section{Angkatan Kerja Menurut Sumber Mata Pencaharian}

Bagi sebagian besar penduduk di pedesaan, secara umum untuk memenuhi kebutuhan hidupnya tidak bergantung pada salah satu sumber matapencaharian saja, namun melakukan beberapa kegiatan yang ada di sektor pertanian dan non petanian. Hasil pengamatan dilapangan menunjukkan bahwa pada tahun 2008, jumlah angkatan kerja yang bekerja pada sumber matapencaharian utama berdasarkan besarnya pendapatan didominasai oleh sumber matapencaharian pada usaha pertanian 65 $\%$ dan kegiatan berburuhtani $10,5 \%$. Sedangkan pada tahun 2011, sumber matapencaharian utama pada usaha pertanian $63,5 \%$ dan kegiatan buruhtani $15,2 \%$. 
Sumber matapencaharian yang lain seperti di sektor non pertanian menyebar keseluruh sumber matapencaharian dengan kisaran dibawah 10\%, baik pada 2008 maupun 2011. Secara keseluruhan (2008), di pedesaan basis komoditas palawija sektor pertanian masih merupakan tumpuan kesempatan kerja bagi angkatan kerja. Kontribusi sektor pertanian terhadap sumber matapencaharian lebih dominan yaitu $75 \%$ dibanding sektor diluar pertanian $25 \%$. Besarnya kontribusi di sektor pertanian lebih banyak ditopang oleh besarnya angkatan kerja yang bekerja pada usaha pertanian hingga $65 \%$ dan di luar sektor pertanian dengan jenis pekerjaan sebagai pedagang hingga $5 \%$. Beberapa desa yang mempunyai kontribusi di sektor pertanian yang terbesar antara lain desa Balleanging 92\%. Sedangkan pada tahun 2011, kontribusi sektor pertanian terhadap sumber matapencaharian lebih dominan sebesar $79 \%$ dibanding sektor diluar pertanian $21 \%$.

Kondisi ini menunjukkan bahwa peluang kesempatan angkatan kerja yang mengisi sumber mata pencaharian di luar sektor pertanian sangat kecil, dan akibat rendahnya mobilitas angkatan kerja kesumber pertumbuhan ekonomi dan akses kepemerintahan, sehingga peluang kesempatan kerja sangat sulit dimasuki oleh angkatan kerja yang bekerja diluar sektor pertanian. Berdasarkan uraian diatas, dapat dikatakan bahwa sumber mata pencaharian utama di pedesaan yang berperan adalah sektor pertanian, utamanya pada kegiatan usahatani dan berburuh tani dibanding bidang pekerjaan lainnya diluar sektor pertanian. Oleh karena itu dalam kegiatan program di pedesaan berbasis komoditas, perlu kiranya ada pembinaan dan bimbingan untuk meningkatkan produksi, serta meningkatkan keseimbangan peluang kerja di luar bidang produksi, maupun di luar sektor pertanian. Sedangkan pekerjaan diluar sektor pertanian yang dominan sangat bervariasi antar desa berbasis komoditas dengan berbagai sumber matapencaharian pada usaha non pertanian (dagang, usaha industri, pegawai tatalaksana, jasa, angkutan, pekerja bangunan dan buruh non pertanian, maupun sumber lainnya)

Secara umum bervariasinya sumber matapencaharian dari masing- masing desa dipengaruhi oleh beberapa hal antara lain: pertama: adanya kesempatan kerja di luar sektor pertanian yang semakin terbuka, kedua: sarana transportasi yang semakin lancar dan komunikasi yang semakin luas membuka peluang untuk akses bekerja diluar sektor pertanian ataupun diluar batas administrasi wilayah hingga ke luar negeri, Ketiga: tingkat pendidikan atau keterampilan dari sebagian tenaga muda di pedesaan mendorong untuk bekerja di luar sektor pertanian dan Keempat: semakin terbatasnya kesempatan kerja dan pemilikan aset produktif yang semakin sempit akan membatasi pola usaha yang lebih produktif dibanding sektor non pertanian yang cenderung terbuka. Sementara itu belum berkembangnya sumber matapencaharian di sektor non pertanian adalah karena: (a) kesempatan kerja di luar sektor pertanian yang terbatas, (b) kesempatan kerja dan bekerja di pertanian belum mengarah pada agroindustri dan masih berorientasi peningkatan produk, (c) ketersediaan tenaga kerja di luar sektor pertanian terbatas, (d) rendahnya sarana dan prasarana komunikasi sehingga pola migrasi dan mobilitas sangat rendah dan (e) keterbatasan informasi pasar tenaga kerja.

\section{Angkatan Kerja Menurut Kelompok Umur dan Matapencaharian}

Dengan mengelompokan angkatan kerja menurut umur dan matapencaharian menunjukan bahwa, jumlah angkatan kerja produktif secara umum yang terbesar jumlahnya pada umur antara 35 54 tahun kebawah mencapai 42,8\% (2008), dan mengalami penurunan menjadi 35,1\% (2011) bekerja disektor pertanian. Konsekuensinya bahwa sektor pertanian merupakan peluang kerja yang dapat dimanfaatkan angkatan kerja dan memberikan sumbangan yang berarti pada pembangunan pertanian. Walaupun dalam posisi tawar angkatan kerja yang lemah karena persaingan pasar tenaga kerja diluar sektor pertanian yang sangat ketat. 
Fenomena angkatan kerja yang ada di pedesaan umumnya bagi mereka yang masuk usia produktif akan mencari peluang kesempatan kerja yang tidak menggantungkan pada sektor pertanian. Namun demikian jumlah angkatan kerja yang masuk usia produktif (15 tahun - 34 tahun) lebih banyak yang bekerja di sektor pertanian yaitu sebesar 16,9\% dibanding diluar sektor pertanian 13,6\% pada tahun 2008. Besarnya tenaga kerja produktif di sektor pertanian, dapat diharapkan mampu meningkatkan produktivitas dan pendapatan petani apabila ditunjang oleh berbagai program dan inovasi teknologi, yang pada akhirnya akan mengurangi beban berat yang selama ini menjadi permasalahan kemiskinan di pedesaan. Besarnya jumlah penyerapan angkatan kerja pada usia produktif di sektor pertanian, akan dapat diharapkan mampu menunjang pembangunan pertanian dengan konsekuensi diperlukan kebijakan melalui berbagai program yang mengarah pada pengembangan industri pertanian yang selaras dengan perkembangan industri di luar pertanian sebagai alternatif penampung tenaga kerja yang produktif.

Dilain pihak peranan sektor diluar pertanian (2011), jumlah terbesar angkatan kerja usia 35 54 tahun kebawah di desa berbasis palawija adalah desa Balleangin (59\%) dan desa Catur Karya sebesar 57\%. Sedangkan pada tahun 2008, jumlah terbesar angkatan kerja usia 35 - 54 tahun kebawah di desa berbasis palawija adalah Sindang Mekar sebesar 24\% dan desa Ngelo sebesar 20\%. Selain pengelompokan angkatan kerja menurut kelompok umur, juga dikelompokan jumlah angkatan kerja berdasarkan tingkat pendidikan. Lebih lanjut pengelompokan jumlah terbesar angkatan kerja di sektor pertanian terjadi pada tingkat pendidikan SD tamat kebawah yaitu 53\% di pertanian dan $10 \%$ diluar pertanian.

Namun demikian, bukan saja pendidikan angkatan kerja terbatas pada tingkat pendidikan SD kebawah, akan tetapi menyebar kependidikan yang lebih tinggi hingga ke perguruan tinggi. Hal ini berarti bahwa sebagian besar di sektor pertanian yang terdiri dari sejumlah angkatan kerja berpendidikan SD kebawah adalah merupakan potensi sumber daya manusia (SDM) yang perlu ditingkatkan melalui berbagai program peningkatan kualitas didalam menunjang pembangunan pertanian. Pengelompokan tingkat pendidikan SD kebawah pada sektor pertanian dari kedua basis komoditas menunjukan bahwa terbesar jumlahnya dengan penidikan SD adalah desa Bumiayu 76\%.

Labih lanjut pengelompokan jumlah terbesar angkatan kerja di sektor pertanian terjadi pada tingkat pendidikan SD tamat kebawah yaitu $60 \%$ di pertanian dan $10 \%$ di luar pertanian. Namun demikian, bukan saja pendidikan angkatan kerja terbatas pada tingkat pendidikan SD kebawah, akan tetapi menyebar kependidikan yang lebih tinggi hingga ke perguruan tinggi. Hal ini berarti bahwa sebagian besar di sektor pertanian yang terdiri dari sejumlah angkatan kerja berpendidikan SD kebawah adalah merupakan potensi sumber daya manusia (SDM) yang perlu ditingkatkan melalui berbagai program peningkatan kualitas didalam menunjang pembangunan pertanian. Pengelompokan tingkat pendidikan SD kebawah dari kedua basis komoditas, menunjukan bahwa desa-desa berbasis komoditas palawija.

\section{Angkatan Kerja Menurut Status Pekerjaan}

Angkatan kerja menurut status pekerjaan dimaksudakan adalah tenaga kerja yang terlibat dalam kegiatan usaha rumahtangga, baik itu kegiatan usaha pertanian maupun nonpertanian. Apakah tenaga kerja tersebut sebagai tenaga kerja upahan, tenaga kerja keluarga atau kombinasi dari keduanya. Sedangkan angkatan kerja yang tidak bekerja adalah sebagian mereka yang termasuk sebagai ibu rumahtangga, anak yang sedang sekolah, angkatan kerja yang sedang menunggu/mencari kerja dan lanjut usia, pensiunan dan cacat/jompo. Prosentase penduduk yang bekerja berdasarkan 
status kerja dan kegiatan migrasi penduduk desa dengan agrosistem lahan kering disajikan dalam tabel 4.

Tabel 4. Prosentase penduduk yang bekerja berdasarkan status kerja dan kegiatan migrasi penduduk desa dengan agrosistem lahan kering tahun 2011

\begin{tabular}{lc}
\hline \multicolumn{1}{c}{ Keterangan } & Tahun 2011 \\
\hline 1 Pekerja berdasarkan status pekerjaan & 10,7 \\
a. Usaha dengan buruh upahan & 42,3 \\
b. Usaha dengan tng kerja dalam keluarga & 5,6 \\
c. Usaha dengan kerja sendiri & 26,6 \\
d. Buruh/bekerja upahan & 14,4 \\
d. Campuran & \\
Tenaga kerja yang melakukan migrasi & \\
A. Berdasarkan jenis migrasi & 40,3 \\
1. Komutasi & 33,2 \\
2. Siskulasi & 26,5 \\
3. Tetap & \\
B. Pekerja migrasi berdasarkan tingkat pendidikan & 56,6 \\
1. Tdk sekolah s/d tamat SD & 23,4 \\
2. Tdk tamat SMP s/d tamat SMP & 17,7 \\
3. Tdk tamat SMA s/d tamat SMA & 0 \\
4. Diploma/perguruan tinggi & \\
C. Mata pencaharian utama para migan & 18,8 \\
1. Buruh pertanian & 11,9 \\
2. Buruh industry & 30,0 \\
3. Pekerja bangunan & 18,5 \\
4. dagang & 2,5 \\
5. Jasa angkutan & 13,9 \\
6. Usaha industry & 4,5 \\
7. Lainnya & \\
\hline
\end{tabular}

Data yang ditampilkan pada tabel 4 menunjukkan bahwa pengelompokkan angkatan kerja yang bekerja berdasarkan status pekerjaan di pedesaan yang terbesar berturut-turut adalah status dengan menggunakan tenaga kerja keluarga 42,3\%, bekerja dengan menggunakan tenaga kerja upahan sebesar $10,7 \%$, dan dengan menggunakan tenaga kerja buruh 26,6\% serta menggunakan tenaga kerja campuran atau kombinasi dari ketiga status tersebut $14,4 \%$.

Pada kelompok status pekerja sebagai buruh tidak dibayar umumnya adalah tenaga kerja keluarga yang membantu kegiatan usaha rumahtangga. Pada kelompok buruh upahan adalah mereka yang memerlukan insentif dalam bentuk upah kerja, serta ketersediaannya merupakan potensi tenaga kerja yang kurang mampu bersaing di pasar tenaga kerja dengan kepemilikan lahan sempit (landless) atau tidak memiliki lahan (tuna kisma). Konsekuensinya di sektor pertanian dengan adanya kedua status pekerjaan tersebut akan menjadi beban yang berat, bila tidak diimbangi penyerapan tenaga kerja diluar sektor pertanian. 
Hasil penelitian Susilowati et al. 2000 menunjukkan bahwa pola (bentuk) hubungan/ikatan kerja antara petani (majikan) dan buruh dapat berupa buruh tetap, langganan, ceblokan dan buruh lepas, baik harian maupun borongan. Bentuk hubungan kerja yang umum dikenal di daerah penelitian di Jawa Tengah adalah hubungan kerja yang tidak terikat dengan upah harian dan borongan. Khusus di daerah perkebunan dan ternak berlaku upah buruh tetap dengan pembayaran mingguan dan dua mingguan. Upah panen pada umumnya memakai sistem bawon dengan kisaran 1:5 sampai dengan 1:10. Upah bawon di daerah padi sawah dataran rendah pada umumnya lebih besar dibandingkan di daerah padi sawah dataran tinggi.

Temuan lain dari Susilowati et al. (2010), menunjukkan bahwa pola hubungan/ikatan kerja antara petani pemilik lahan (majikan) dan buruh dilahan pertanian maka hubungan kerja tersebut dapat berupa buruh langganan tetap, buruh lepas harian dan borongan. Namun demikian dalam realisasinya alokasi tenaga kerja dalam keluarga masih mendominasi kegiatan. Sejak kegiatan olah tanah sampai dengan kegiatan pasca panen, penggunaan tenaga kerja dalam keluarga lebih mendominasi. Artinya bahwa dominasi curahan kerja dalam keluarga yang terjadi hampir disetiap kegiatan usahatani menunjukkan bahwa peluang untuk berburuh tani di wilayah desa dengan basis komoditas sayuran dapat dikatakan tidak terlalu banyak. Salah satu sebab rendahnya peluang berburuh tani di desa dengan agroekosistem lahan kering dengan komoditas utama sayuran adalah skala kepemilikan dan penguasaan lahan yang relatif sempit.

\section{Produktivitas Kerja}

Mengetahui produktivitas tenaga kerja adalah hal penting di dalam analisis biaya langsung dalam suatu usaha. Produktivitas merupakan kemampuan tenaga kerja dalam berproduksi yang biasanya dinilai dari satuan hitung yang dibutuhkan. Tetapi faktual di lapangan, pengukuran produktivitas adalah satu hal yang sulit dilakukan. Namun demikian pengukuran produktivitas tenaga kerja tetap diperlukan untuk estimasi biaya upah pada perhitungan harga satuan pekerjaan. Secara umum definisi produktivitas adalah rasio antara input dan output. Pada proses perhitungannya perlu dideskripsikan dengan jelas pengertian input dan output yang dimaksud. Untuk produktivitas tenaga kerja pengertian input diekspresikan sebagai orang jam(OJ) atau orang-hari $(\mathrm{OH})$, sedangkan output adalah kuantitas hasil kerja yang satuannya bervariasi tergantung jenis pekerjaan yang diukur.

Produktivitas yang dinilai dalam besar pendapatan per satuan kerja, menunjukkan tingkat produktivitas tenaga kerja rumahtangga yang bekerja sebagai buruh tani dan buruh non pertanian. Hasil pengamatan dilapangana menunjukkan bahwa kisaran produktivitas tenaga kerja di desa komoditas basis palawija berkisar antara Rp 17.000 - Rp 36.000 per HOK. Umumnya produktivitas tenaga kerja kegiatan berburuh tani di pedesaan luar Jawa (Sulawesi Selatan) lebih tinggi dibanding di pedesaan Jawa. Produktivitas tenaga kerja rumah tangga kegiatan berburuh non pertanian.

\section{Keadaan Angkatan Kerja yang Bermigrasi}

Migrasi angkatan kerja bagi masyarakat di pedesaan banyak dipengaruhi oleh beberapa faktor seperti kondisi ekonomi keluarga, kondisi sumberdaya alam yang marginal dan daya tarik atau pendorong yang meyebabkan mereka harus melakukan migrasi. Migrasi angkatan kerja dikatagorikan menurut sumber mata pencaharian antara lain: Pertama. migrasi yang terjadi karena perpindahan antar sektor atau didalam subsektor pendukungnya dan Kedua: migrasi yang terjadi karena perubahan wilayah adminsitrasi. Sedangkan dilihat dari jenis migrasi dapat terjadi karena; (a) Kejadian migrasi yang dilakukan dengan cara pulang-pergi dari rumah ketempat kerja yang disebut dengan migarsi komutasi, (b) migrasi yang dilakukan dengan menginap kurang dari 6 bulan yang disebut dengan 
migrasi sikulasi dan (c) migrasi yang dilakukan dengan cara menginap di tempat migrasi lebih dari 6 bulan yang disebut dengan migrasi menetap.

Cara migrasi yang dilakukan oleh masyarakat di pedesaan, menunjukan bahwa di pedesaan berbasis palawija jumlahnya cukup besar. Salah satu faktor tingginya tingkat migrasi di pedesaan berbasis komoditas palawija adalah keterbatasan sumberdaya alam dan kondisi lahan yang marjinal. Sehingga akan mempengaruhi tingkat produktivitas lahan yang rendah, intensitas tanam yang rendah, yang aklhirnya mempengaruhi tingkat pendapatan yang rendah. Selain itu ada daya tarik yang kuat, seperti pendapatan diluar sektor pertanian yang lebih tinggi dibanding penadapatan yang diperoleh di dalam desa.

Data pada tabel 4 menunjukkan bahwa jumlah migran menurut tingkat pendidikan menunjukan bahwa secara agregrat berpendidikan SD kebawah 56,6\%, kemudian tamat SMP 23,4\% dan tamat SMA $17,7 \%$ dan yang lainnya (diploma dan perguruan tinggi) tidak ada sama sekali. Jumlah angkatan kerja yang bekerja dengan migrasi berpendidikan SD kebawah tertinggi adalah desa Resongo 89\% dan Sindang Mekarsebesar 67\%. Besarnya tingkat pendidikan SD kebawah yang bermigrasi pada umumnya kurang berkompetisi dengan angkatan kerja yang berpendidikan tinggi, yang akhirnya akan mengisi peluang kesempatan kerja yang sama dengan yang mereka lakukan di daerah asalnya sebagai pekerja kasar, seperti buruh dan jasa angkutan.

Berbeda dengan mereka yang berpendidikan lebih tinggi yang mudah berkompetisi untuk mengisi kesempatan kerja sesuai dengan tingkat pendidikan yang mereka miliki. Seiring dengan perbedaan jenjang pendidikan diantara para migran, jenis pekerjan yang diperoleh sangat bervariasi sebanding dengan tingkat pendidikan yang dimiliki. Jumlah persentase migran yang terbesar menurut sumber matapencaharian adalah bekerja diluar sektor pertanian seperti pekerja bangunan 30,00\%, dagang $18,5 \%$ dan buruh pertanian $18,8 \%$. Rendahnya penyerapan disektor pertanian dibanding di luar sektor pertanian, karena kurangnya kompetisi upah dan pendapatan yang mereka terima umumnya lebih kecil dibanding di luar sektor pertanian.

Siregar (2000), mengemukakan bahwa di wilayah pinggiran perkotaan, pengembangan pertanian ternyata memegang peranan penting, utamanya untuk menampung tenaga kerja pengangguran terutama para migran untuk kegiatan usahatani sayuran seperti kangkung, caisim dan selada. Sementara itu kasus menunjukkan bahwa petani responden di Jakarta mampu memperoleh penerimaan bersih sebesar Rp.13,9 juta/tahun dengan curahan tenaga kerja $871 \mathrm{HOK} /$ tahun dimana 55\% merupakan tenaga kerja keluarga. Sedang di Surabaya untuk kegiatan budidaya sawi, kangkung dan bayam ternyata mampu mendatangkan pendapatan sebesar Rp.12,2 juta/tahun dengan curahan tenaga kerja $632 \mathrm{HOK} /$ tahun terdiri atas $85 \%$ merupakan tenaga kerja keluarga.

\section{KESIMPULAN DAN IMPLIKASI KEBIJAKAN}

Sektor pertanian merupakan sektor yang merupakan tumpuan dalam penyerapan tenaga kerja di pedesaan. Permasalahannya tidak semua pedesaan merupakan desa yang berlokasi di kawasan lahan dengan agorsistem yang mampu memberikan sumbangan pendapatan yang bisa diharapkan. Tidak sedikit masyarakat yang tinggal di pedesaan dengan agrosistem lahan kering. Dimana lahan sebagian kering kering merupakan lahan marginal yang kurang mampu memberikan kesejahteraan bagi penduduknya. Komoditas tanaman pangan khususnya jagung, kedelai dan kacang tanah merupakan komoditas utama yang banyak dikembangkan di wilayah seperti tersebut. Dengan kondisi yang 
demikian tidak sedikit penduduk terutama penduduk usia kerja harus meninggalkan kegiatan pertanian dengan maksud untuk memperbaiki mata pencaharian.

Permasalahannya sebagian penduduk usia kerja dihadapkan pada ketrampilan dan pendidikan yang terbatas, sehingga kurang memiliki posisi tawar yang kuat di pasar tenaga kerja. Kalaupun mereka harus bermigrasi mengadu nasib ke tempat yang baru, maka pekerjaan yang ditemukan umumnya tidak terlalu jauh dengan pekerjaan di tempat asal sesuai dengan ketrampilan mereka. Hanya peluang pekerjaan dengan pendapatan rendah seperti buruh non pertanian, jasa angkutan, dagang dan pekerjaan yang sejenis yang akhirnya mereka dapatkan di tempat yang baru. Untuk meningkatkan kualitas kemampuan sumberdaya manusia (SDM) di pedesaan, diperlukan program peningkatan ketrampilan dan pengetahuan sehingga tenaga kerja dapat bersaing di pasar tenaga kerja dan produktivitas tenaga kerja dapat ditingkatkan. Disisi lain pemerintah perlu mengembangkan industri pertanian di perdesaan untuk menampung tenaga kerja, mengingat intensitas pekerjaan usahatani di lahan tegalan dengan basis palawija relatif kurang.

\section{DAFTAR PUSTAKA}

Malian, A. H., S. Friyatno, S. K. Darmoredjo, S. Mardiyanto, M. Suryadi, M. Maulana. 2004. Analisis Pekembangan Aset, Kesempatan Kerja dan Pendapatan Rumahtangga di Sektor Pertanian. Pusat Penelitian Dan Pengembangan Sosial Ekonomi Pertanian, Bogor.

Marisa, Y, dan B. Hutabarat. 1988. Ragam Sumber Pendapatan Rumahtangga di Pedesaan Sulawesi Selatan Dalam F, Kasryno dkk (eds). Prosiding Patanas: Perubahan Ekonomi Pedesaan menuju Struktur Ekonomi Berimbang. Puslit Agro Ekonomi. Hal: 314 -320.

Rusastra, I. W., K. M. Noekman, Supriyati, E. Suryani, M. Suryadi dan R. Elizabeth. 2005. Analisis Ekonomi Ketenagakerjaan Sektor Pertanian dan Pedesaan di Indonesia. Laporan Hasil Penelitian. Pusat Sosial Ekonomi dan Kebijakan Pertanian, Kementerian Pertanian, Bogor.

Siregar, M. 2000. Studi PATANAS: Studi Kesempatan kerja dan Pendapatan Petani Pinggiran erkotaan. PuslitbangSosialEkonomiPertanian. Bogor.

Susilowati, S. H., B. Hutabarat, M. Rachmat, Sugiarto, Supriyati, A.K. Zakaria, H. Supriyadi, A. Purwoto, Supadi, B. Winarso, M. Iqbal, D. Hidayat, T.B. Purwantini, R. Elizabeth, C. Muslim, T. Nurrasa, M. Maulana dan R. Aldillah. 2010. Indikator Pembangunan Pertanian Dan Pedesaan: Karakteristik Sosial Ekonomi Petani dan Usahatani Padi. Laporan Hasil Penelitian. Pusat Analisis Sosial Ekonomi dan Kebijakan Pertanian. Bogor.

Susilowati, S. H, Chaerul Saleh, Amar Zakaria, Sri Wahyuni, Supriati, Supadi, Waluyo, Tjetjep Nurasa. 2001. Studi Dinamika Ekonomi Pedesaan (PATANAS): Usahatani, Ketenagakerjaa, Pendapatan Konsumsi. Puslitbang Sosial Ekonomi Pertanian. Badan Litbang Pertanian. Departemen Pertanian. Bogor.

Susilowati, S. H. dan E. Suryani. 2000. Struktur dan Distribusi Pendapatan Rumah Tangga di Pedesaan Jawa Tengah. Dalam Rusastra, I.W. et al. (eds). Prosiding: Perspektif Pembangunan Dalam Otonomi Daerah. Pusat Penelitian Sosial Ekonomi Pertanian, Bogor. 
Sholeh M (2007). Permintaan dan penawaran Tenaga Kerja Serta Upah Teori Serta Beberapa Potretnya di Indonesia. Jurnal Ekonomi dan Pendidikan Vol. 4 No.1.

Sudaryanto T dan Rusastra W, (2006) Dalam Kebijakan Strategis Usaha Pertanian Dalam Rangka Peningkatan Produksi dan Pengentasan Kemiskinan. Jurnal Litbang Pertanian, 25 (4).

Supriyati (2010). Dinamika Ekonomi Ketenagakerjaan Pertanian: Pusat Analisis Sosial Ekonomi dan Kebijakan Pertanian. Permasalahan dan Kebijaksanaan Strategis Pengembangan. Analisis Kebijaksanaan Pertanian Vol. 8 No. 1.

Susilowati dkk. 2010, Indikator Pembangunan Pertanian dan Pedesaan; Karakteristik Sosial Ekonomi Petani dan Usahatani Padi. Pusat Sosial Ekonomi dan Kebijakan Pertanian. Badan Litbang Pertanian.

Syukur, M, H. P.S. Rachman dan S.M. Pasaribu. 1988. Pola dan Distribusi Pendapatan Rumahtangga di Pedesaan Jawa Barat. Dalam F. Kasryno dkk (eds). Prosiding Patanas: Perubahan Ekonomi Pedesaan menuju Struktur Ekonomi Berimbang. Puslit Agro Ekonomi. Hal: 299-313.

White, B. 1990. Agro Industri, Industrialisasi Pedesaan Dan Transformasi Pedesaan. Makalah disampaikan pada Seminar Industrialisasi Pedesaan, Kerjasama antara Pusat Studi Pembangunan Lembaga Penelitian IPB dan ISEI Cabang Jakarta 